\title{
HUBUNGAN PERHATIAN ORANG TUA DAN MINAT BELAJAR TERHADAP PRESTASI BELAJAR SISWA
}

\author{
Syeilla Pingkan Pondaag ${ }^{1}$, Titof Tulaka² ${ }^{2}$, A.L.G. Katuuk ${ }^{3}$ dan Metsi Daud ${ }^{4}$ \\ Pendidikan Teknik Bangunan Fakultas Teknik Univeritas Negeri Manado \\ Email: pingkansye@gmail.com
}

\begin{abstract}
ABSTRAK
Penelitian ini dilatarbelakangi oleh pengaruh atau peranan orang tua dan minat belajar siswa. Tujuan penelitian ini adalah untuk menganalisis pengaruh perhatian orang tua, dan minat belajar terhadap prestasi belajar siswa SMK Negeri 1 Tomohon. Penelitian ini menggunakan metode survey dengan pendekatan kuantitatif yang bertujuan untuk mengidentifikasi apakah ada pengaruh perhatian orang tua dan minat belajar terhadap prestasi belajar siswa. Kesimpulan yang diperoleh dari penelitian ini adalah : 1) Perhatian orang tua mempengaruhi prestasi belajar siswa pada Mata Pelajaran Menggambar Teknik Pada Siswa Teknik Keahlian Teknik Gambar Bangunan SMK Negeri 1 Tomohon. 2) Minat mempengaruhi prestasi belajar siswa pada Mata Pelajaran Menggambar Teknik Pada Siswa Teknik Keahlian Teknik Gambar Bangunan SMK Negeri 1 Tomohon. 3) Perhatian orang tua dan minat mempengaruhi prestasi belajar siswa pada Mata Pelajaran Menggambar Teknik Pada Siswa Teknik Keahlian Teknik Gambar Bangunan SMK Negeri 1 Tomohon.
\end{abstract}

Kata Kunci: perhatian orang tua, minat belajar, dan prestasi belajar.

\section{ABSTRACT.}

This research is motivated by the influence or role of parents and student learning interests. The purpose of this study is to analyze the influence of parental attention, and learning interests on the learning achievement of students of SmK Negeri 1 Tomohon.The study used a survey method with a quantitative approach aimed at identifying whether there was an influence on parental attention and learning interests on students' learning achievement.The conclusions obtained from this study are: 1) Parental attention affects students' learning achievement in Engineering Drawing Subjects In Engineering Students Building Engineering Expertise SMK Negeri 1 Tomohon.2) Interest affects students' learning achievement in Engineering Drawing Subjects In Engineering Students Building Engineering Expertise SMK Negeri 1 Tomohon.3) Parental attention and interest affect students' learning achievement in Engineering Drawing Subjects In Engineering Students Building Engineering Skills SMK Negeri 1 Tomohon.

Keywods: Parental attention, learning interests, and learning achievemen 


\section{PENDAHULUAN}

A. Latar Belakang Masalah Pendidikan di dalam keluarga merupakan pendidikan kodrati. Apalagi setelah anak lahir, pengenalan diantara orang tua dan anak-anaknya yang diliputi rasa cinta kasih, ketentraman dan kedamaian. Anak-anak akan berkembang kearah kedewasaan dengan wajar di dalam lingkungan keluarga segala sikap dan tingkah laku kedua orang tuanya sangat berpengaruh terhadap perkembangan anak, karena ayah dan ibu merupakan pendidik dalam kehidupan yang nyata dan pertama sehingga sikap dan tingkah laku orang tua akan diamati oleh anak baik disengaja maupun tidak disengaja sebagai pengalaman bagi anak yang akan mempengaruhi pendidikan selanjutnya. Maka, keluarga yang baik di dalamnya akan terjadi interaksi diantara para anggotanya.

Dengan demikian seseorang yang mempunyai perhatian dan hubungan yang baik (bukan broken home), cenderung mempunyai kesanggupan yang lebih besar untuk menyesuaikan diri dengan lingkungannya, memecahkan masaah- masalah yang dihadapi secara cepat dan tepat, termasuk masalah-masalah dalam rangka meraih prestasi yang optimal.

B. Identifikasi Masalah

$$
\text { Alasan-alasan yang }
$$
mendorong penulis untuk memilih judul penelitian diatas maka dapat diidentifikasikan permasalahan sebagai berikut :

\section{Adanya kecenderungan menurunnya prestasi belajar yang dicapai siswa- siswa di SMK negeri 1 Tomohon.}

2. Salah satu indikator yang menyebabkan prestasi belajar siswa menurun adalah pengaruh perhatian orang tua, yang kurang baik.

3. Disisi lain diagnosa minat belajar didalam dunia pendidikan dirasa cukup penting dan perlu untuk dibahas dan diteliti. Karena Minat Belajar mempunyai hubungan yang cukup tinggi dengan hasil prestasi belajar siswa.

C. Batasan Masalah

Masalah yang berhubungan dengan prestasi belajar siswa sangatlah kompleks. Oleh karena itu, dengan pertimbangan efektivitas dan agar supaya masalah penelitian tersebut dapat dicari solusinya, maka dalam penelitian ini permasalahannya hanya dibatasi pada pengaruh perhatian orang tua dan minat belajar terhadap prestasi siswa SMK Negeri 1 Tomohon.

D. Rumusan Masalah

Dalam latar belakang telah dijelaskan tentang pengaruh perhatian orang tua dan minat belajar dengan prestasi belajar siswa. Dari masalah-masalah yang ada dapat dirumuskan permasalahan sebagai berikut :

1. Apakah ada hubungan antara perhatian orang tua dan prestasi belajar siswa SMK Negeri 1 Tomohon?

2. Apakah ada hubungan antara minat belajar dan prestasi belajar siswa SMK Negeri 1 Tomohon?

3. Apakah ada hubungan yang signifikan antara perhatian orang tua dan peran orang tua terhadap prestasi belajar siswa SMK Negeri 1 Tomohon?

E. Tujuan Penelitian

Dalam pelaksanaan 
penelitian ini penulis mempunyai tujuan yang hendak dicapai yaitu :

1. Untuk mengetahui ada tidaknya pengaruh perhatian orang tua dan minat belajar dengan prestasi belajar siswa.

2. Untuk mengetahui ada tidaknya hubungan antara minat belajar dengan prestasi belajar siswa.

3. Untuk mengetahui bagaimana peran orang tua terhadap siswa atau anak.

F. Manfaat Penelitian

Adapun dari hasil penelitian ini, diharapkan dapat memberikan manfaat

bagi :

1. Bagi Guru

Dapat memberikan motivasi kepada siswa agar lebih giat belajar dirumah dengan bantuan orang tua.

\section{Bagi Siswa}

Dengan hadirnya penelitian yang ada ini, diharapkan dapat menambah pengetahuan dan selalu berprestasi.

\section{Bagi Orang Tua}

Kiranya dengan penelitian ini, orang tua mampuh menbrikan perhatian kepada anaknya agar lebih giat belajar sehingga dapat berprestasi.

\section{Bagi peneliti}

Dapat memperoleh wawasan, pengalaman serta dapat mengetahui sangat memprihatinkan siswa SMK Negeri 1 Tomohon khususnya perhatian orang tua terhadap anaknya.

\section{LANDASAN TEORI}

1. Perhatian orang tua

Perhatian dapat dibedakan berdasarkan objek tertentu yang disertai aktivitas. Dalam penelitian ini perhatian orang tua terhadap anak disimpulkan sebagai pemusatan tenaga psikis yang tertuju pada suatu objek yang dilakukan oleh orang tua (ayah, ibu atau wali) yang berupa : perhatian spontan, perhatian refleksi, perhatian intensif, perhatian terpusat dan perhatian terpencar.

2. Minat Belajar

Minat adalah kecenderungan dalam diri individu untuk tertatik pada sesuatu objek atau menyenangi sesuatu objek (Sumadi Suryabrata, 1988:109).

Menurut Crow and Crow minat adalah pendorong yang menyebabkan seseorang memberi perhatian terhadap orang, sesuatu, aktivitas-aktivitas tertentu. (Johny Killis, 1988:26). Berdasarkan pendapat Crow and Crow dapat diambil pengertian bahwa individu yang mempunyai minat terhadap belajar, maka akan terdorong untuk memberikan perhatian terhadap Belajar tersebut.

\section{Prestasi Belajar Siswa Prestasi}

Belajar Siswa tidak dapat dipisah kan dari kegiatan belajar, karena belajar merupakan suatu proses, sedangkan prestasi belaja $r$ adalah hasil dari proses pembe lajaran tersebut. Bagi seorang a nak belajar merupakan suatu ke wajiban. Berhasil atau tidaknya seorang anak dalam pendidikan tergantung pada pros es belajar yang dialami oleh anak tersebut.

\section{Kerangka Berpikir}

Hubungan antara pengaruh Perhatian Orang Tua dan Prestasi Belajar Siswa

Membiasakan anak hidup teratur, tertib, disiplin, sopan, santun baik dalam keluarga 


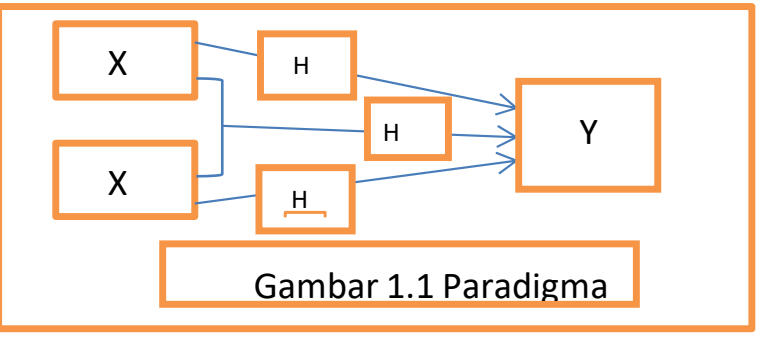

maupun dengan lingkungan diluar keluarga. Semua ini diarahkan pula untuk menanamkan jiwa kemandirian dan sebagai modal untuk menumbuhkan profesionalisme, mencapai prestasi belajar di sekolah yang sangat diperlukan dalam masa depannya. Hubungan Pengaruh antara Minat Belajar dan Prestasi Belajar Siswa Dalam hubungan yang terakhir ini misalnya persoalan mengenai pemilihan jurusan / pilihan program bidang studi pada lembaga-lembaga pendidikan formal. Sebaliknya pilihan program terhadap bidang studi itu dipilih yang benar-benar dengan minat para siswa, karena dengan demikian dapat diharapkan hasil dan prestasi belajar yang lebih baik.

Hubungan Antara Perhatian Orang Tua dan Minat Belajar dengan Prestasi Belajar Siswa

faktor yang mempengaruhi prestasi belajarpun dapat terjadi saling berhubungan antara faktor yang satu dengan faktor yang lain. Dan minat memiliki daya prediksi yang tinggi terhadap perilaku seseorang. Sehingga seseorang yang mempunyai minat untuk belajar tinggi atau keras, maka dalam dirinya akan muncul dorongan psikologis yang sangat kuat untuk mempersiapkan diri untuk belajar.

Paradigma Penelitian

Berdasarkan kerangka berpikir di atas, dapat digambarkan hubungan ketiga variabelpenelitian tersebut dalam paradigm penelitian sebagai berikut :

Ket:

$\mathrm{X} 1$ : Perhatian Orang Tua

X2 : Minat Belajar

$\mathrm{Y}$ : Prestasi Belajar

\section{METODE PENELITIAN}

Muhammad Ali (198: 81) mengatakan bahwa pendekatan penelitian merupakan keseluruhan cara atau kegiatan yang dilakukan oleh peneliti dalam melaksanakan penelitian mulai dari perumusan masalah sampai dengan penarikan kesimpulan.

1. Pendekatan Kuantitatif, artinya bahwa seorang peneliti harus bekerja dengan angka-angka sebagai perujudan dari gejala yang diamati, sehingga memungkinkan digunakan analisis statistic.

2. Pendekatan Kualitatif, artinya seorang peneliti bekerja dengan informasiinformasi, keteranganketerangan dan penjelasan data. Tehnik analisanya yang digunakan adalah tehnik non statistic / dengan prinsip (1988:1)

Penelitian ini bila dilihat dari hadirnya variabel maka disebut penelitian deskriptif, karena variabel yang dipakai menggambarkan variabel yang sudah ada datanya sekarang. Pendapat senada dikutip oleh Suriswo, menyatakan bahwa penelitian yang dilakukan dengan menjelaskan atau menggambarkan variabel masa lalu dan sekarang (sedang terjadi), adalah penelitian deskriptif (2005:30). Sifat dari penelitian adalah ex post facto 
karena pengumpulan data
dilakukan $\begin{array}{r}\text { setelah kejadian } \\ \text { berlangsung. }\end{array}$
Hal ini sesuai dengan kutipan Suriswo, (2005:35) yang mengatakan bahwa, metode penelitian komparatif adalah bersifat ex post facto. Artinya, data dikumpulkan setelah semua kejadian yang dikumpulkan telah selesai berlangsung.

Tempat Dan Waktu Penelitian Penelitian ini dilakuakan di SMK Negeri 1 Tomohon pada Keahlian Teknik Gambar Bangunan . Dengan rencana waktu penelitian 3 bulan dari bulan april sampai pada juni 2021.

Tempat Dan Waktu Penelitian

Penelitian ini dilakuakan di SMK Negeri 1 Tomohon pada Keahlian Teknik Gambar Bangunan . Dengan rencana waktu penelitian 3 bulan dari bulan april sampai pada juni 2021.

Populasi dan Sampel

Menurut Arikunto (2007:68) populasi adalah keseluruhan obyek penelitian, yaitu elemen-elemen yang ada dalam wilayah penelitian. Sebagai populasi dalam penelitian ini adalah semua siswa SMK Negeri 1 Tomohon Keahlian Teknik Bangunan yang berjumlah 52 siswa.

Merurut Arikunto (2006:94) menyatakan bahwa untuk pengambilan sampel, sekedar ancer-ancer maka apabila subyeknya kurang dari 100 orang, lebih baik diambil semua sehingga penelitiannya merupakan penelitian populasi. Akan tetapi, jika jumlah subyeknya lebih besar dapat diambil antara 10-15\% atau 20-25\% atau lebih.

Berdasarkan pernyataan diatas, dalam penentuan jumlah sampel, penulis menggunakan semua jumlah populasi yang berjumlah 52 orang yang terdiri dari 3 Kelas untuk dijadikan sampel penelitian yang terdiri dari

Kelas X Jurusan Teknik Bangunan sebanyak 19 Orang

Kelas XI Jurusan Teknik bangunan sebanyak 15 Orang, serta

Kelas XII Jurusan Teknik Bangunan sebanyak 18 Orang.

Teknik Pengumpulan Data

Metode Angket (Kuisioner)

Metode angket (Kuisioner) adalah sejumlah pertanyaan tertulis yang digunakan untuk memperoleh informasi dari responden dan arti-arti laporan tentang pribadinya, atau hal-hal yang diketahui" (Suharsini Arikunto, 1997:124).

Metode Dokumentasi

Dalam penelitian ini yang dimaksud dokumentasi menurut Winarno Surakhmad adalah "Suatu metode pengumpulan data dengan jalan melihat catatan yang sudah ada" (1985:100). Untuk melihat catatan yang sudah ada peneliti dapat mengambilnya dari nilai tes, surat kabar, traskrip, agenda rapat, nilai raport, dan sebagainya.

\section{Teknik Analisis Data}

Variabel Penelitian

Variabel adalah objek penelitian atau apa yang menjadi titik perhatian suatu penelitian (Arikunto 2006:118) Variabel Bebas (X)
a. Perhatian Orang Tua

b. Minat $\left(\mathrm{X}_{2}\right)$

Variabel Terikat (Y)

Variabel terikat dalam penelitian ini adalah prestasi belajar siswa kelas X, XI, XII 
Teknik Gamnbar Bangunan yang telah dicapai dalam usaha belajar pada mata pelajaran Menggambar Teknik di SMK Negeri 1 Tomohon. Pengukuran prestasi belajar dilihat dari hasil nilai ujian semester ganjil tahun ajaran 2020/2021.

\section{Definisi Operasional Variabel \\ 1. Perhatian Orang Tua $\left(\mathrm{X}_{1}\right)$}

Perhatian orang tua adalah merupakan bentuk kasih sayang, kepedulian maupun simpati terhadap peserta didik SMK Negeri 1 Tomohon dalam rangka membangun semangat siswa untuk belajar Di rumah maupun Di sekolah.

2. Minat $\left(\mathrm{X}_{2}\right)$

Minat belajar adalah suatu ketertarikan terhadap pelajaran yang kemudian mendorong peserta didik SMK Negeri 1 Tomohon dalam rangka mempelajari dan menekuni pelajaran tersebut.

3. Prestasi Belajar (Y)

\begin{tabular}{|c|c|}
\hline $\begin{array}{ll} & \text { Varia } \\
\text { bel } & \\
\end{array}$ & Cronbach`s Alpha \\
\hline Perhatian Orang Tua & 0,932 \\
\hline Minat Belajar Siswa & 0,929 \\
\hline
\end{tabular}

Prestasi belajar adalah hasil yang diperoleh dari suatu aktivitas. Sedangkan belajar adalah suatu proses yang mengakibatkan perubahan dalam individu, yakni perubahan tingkah laku.

Instrumen Penelitian

Uji instrumen dalam penelitian ini menggunakan uji validitas dan reliabilitas.

a. Uji Validitas

Suatu instrument yang valid atau sahim mempunyai validitas yang tinggi, sebaliknya instrument yang kurang Valid berartui memiliki validitas yang rendah.
Pengujian validitas untuk instrument perhatian orang tua $\left(\mathrm{X}_{1}\right)$ dan minat belajar $\left(\mathrm{X}_{2}\right)$ menggunakan rumus Product moment dari Pearson.

b. Uji Reliabilitas

Reliabitas menunjukan pada suatupengertian bahwa suatu instrument cukup dapat dipercaya untuk dapat digunakan sebagai alat pengumpulan data karena instrument tersebut sudah baik (Suharsimi, 2010:221). Reliabitas artinya dapat dipercaya, jadi dapat diandalkan. Penelitian ini menggunakan reabilitas internal yaitu menghitung reabilitas berdasarkan data dan instrument yang telah dibuat sebelumnya. Untuk menguji reabilitas instrument digunakan rumus $r$ Alpha.

Menurut Setiono (2013:28), dasar pengambilan keputusan reabilitas adalah dengan mencari $\mathrm{r}$ Alpha. Jika r Alpha positif dan $\mathrm{r}$ Alpha $>0,6$ maka variable tersebut reliabel, sedangkan jika r Alpha positif dan $\mathrm{r}$ Alpha $<0,6$ maka variabel tersebut tidak reliabel.

Reabilitas

Table 3.2 Hasil Uji

Dari perhitungan menggunakan Statistic Package For Sosial Science (SPSS) V 22 diperoleh hasil bahwa $\mathrm{r}$ Alpha positif dan $\mathrm{r}$ Alpha $>0,6$ maka variabel-variabel tersebut reliabel. Sehingga instrument-instrument tersebut dapat dilanjudkan untuk penelitian berikutnya.

Uji Asumsi Klasik

Uji Normalitas

Uji normalitas bertujuan untuk menguji apakah model regresi variabel terikat dan variabel bebas mempunyai distribusi normal atau tidak. Model regresi 
yang baik adalah yang memiliki distribusi normal atau mendekati normal. Selain itu juga bias menggunakan one sample Kolmogorov- smirnov test (dengan menggunakan SPSS V 22).

Uji Linearitas

Uji linearitas digunakan untuk mengetahui apakah dua variabel memiliki hubungan yang linear atau tidak secara signifikan. Pengujian ini digunakan sebagai persyaratan dalam analisis korelasi atau regresi linear. Uji dilakukan dengan mencari persamaan garis regresi variabel bebas $(\mathrm{X})$ terhadap variabel terikat $(\mathrm{Y})$. (Arikunto, 2010: 145)

\section{Hipotesis Statistik}

Hipotesis Statistik merupakan suatu pernyataan tentang bentuk fungsi suatu variabel atau tentang nilai sebenarnya suatu parameter. Suatu pengujian hipotesis statistic ialah prosedur yang memungkinkan keputusan dapat dibuat, yaitu keputusan untuk keputusan menolak atau tidak menolak hipotesis yang sedang diuji.

Ha : Terdapat pengaruh perhatian orang tua dan minat terhadap prestasi belajar siswa SMK Negeri 1 Tomohon.

Ho : Tidak terdapat pengaruh perhatian orang dan minat terhadap prestasi belajar siswa SMK Negeri 1 Tomohon.

\section{HASIL DAN PEMBAHASAN}

A. Hasil Penelitian

\section{Deskripsi Data}

Penelitian ini bertujuan untuk mengetahui hubungan yang signifikan antara Perhatian Orang Tua $\left(\mathrm{X}_{1}\right)$ Dan Minat Belajar $\left(\mathrm{X}_{2}\right)$ terhadap Prestasi Belajar (Y). sampel dalam penelitian ini adalah peserta didik kelas X, XI dan XII yang berjumlah 52 orang.

a. Perhatian orang tua

Jumlah instrument angket perhatian orang tua sebanyak 25 butir pernyataa (Melalui uji validitas dan uji reliabilitas di lampiran 7 dan 8 dan jumlah instrument angket minat sebanyak 25 butir pertanyaan dinyatakan valid serta reliable.

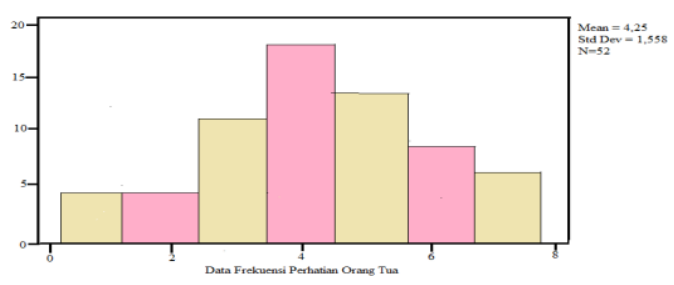

Gambar 2.1

\section{Histogram Perhatian} Orang Tua

b. Minat Belajar

Data variabel ini diperoleh melalui angtket dengan jumlah item sebanyak 25. Adapun skor yang digunakan dalam angket tersebut adalah 1 sampai 5, sehingga berdasarkan skor tersebut maka variabel minat memiliki rentang skor dari 20 sampai 100 .

Berdasarkan data induk angket yang diperoleh dari responden pada penelitian ini yang telah ditabulasi (lihat pada table tabulasi data di lampiran 5). Maka variabel minat belajar diperoleh skor terendah adalah 73 tertinggi adalah 100 .

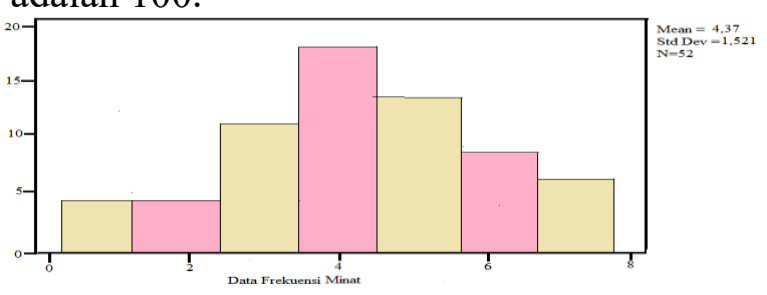

Gambar 2.2

Histogram Minat Belajar

c. Prestasi Belajar

Data prestasi belajar siswa diperoleh dari nilai rata-rata ujian akhir semester ganjil tahun ajaran 
Jurnal Gearbox Pendidikan Teknik Mesin

ISSN 2774-7697 (media online)

Volume 2 Nomor 2, Desember 2021 Hal 105-116

http://ejurnal-mapalus-unima.ac.id/index.php/gearbox

2020/2021 siswa (lihat lampiran

2). Maka memperoleh skor terendah adalah 50 dan skor tertinggi adalah 85 .

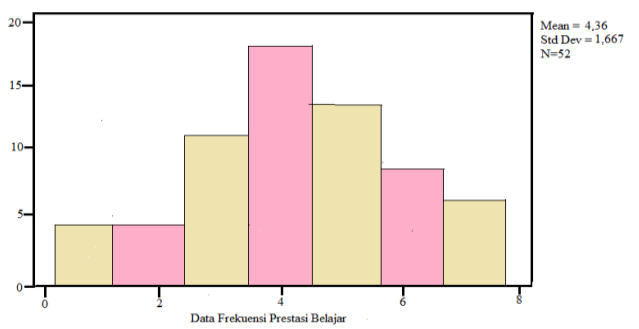

Gambar 2.3

Histogram Prestasi

Belajar Siswa

Pengujian Persyaratan Analisis Statistik

Uji Normalitas Data

Pengujian normalitas dalam penelitian ini menggunakan uji kolmogrov-smirnov. Variabel yang diuji adalah perhatian orang tua, minat dan prestasi belajar.

Syarat data variabel tersebut berdistribusi normal adalah jika nilai sig.kolmogrov-smirnov $>0,05$. Berikut hasil uji normalitas seperti terlihat pada tabel 4.4 dan tabel 4.5 adalah hasil uji normalitas pada variabel- variabel yang digunakan.

Tabel 4.4

Descriptive Statistik

\begin{tabular}{|c|c|c|c|c|c|c|c|}
\hline \multirow{3}{*}{\multicolumn{2}{|c|}{$\mid \mathrm{N}$}} & & \multirow{3}{*}{$\begin{array}{l}\text { Std. } \\
\text { Deviation }\end{array}$} & \multirow{3}{*}{ Min } & \multirow{2}{*}{ Maxfferences } & \multirow{2}{*}{$\begin{array}{l}\text { Aosorule } \\
\text { Positive }\end{array}$} & \multirow{2}{*}{,093 } \\
\hline & & & & & & & \\
\hline & & & & & & Negative &,- 096 \\
\hline Perhatian 5 & 52 & 88,19 & 6,633 & 73 & 100est Statistic & & 096 \\
\hline Orang & & & & & Asymp. Sig. (2 & &, $200^{\mathrm{c}}$ \\
\hline
\end{tabular}

Tabel 4.5

One-Sample Kolmogorov-Smirnov Test

\begin{tabular}{|l|l|}
\hline & Perhatian Orang Tua \\
\hline $\mathrm{N}$ & 52 \\
\hline Normal Mean & 88,19 \\
\hline Parameters ${ }^{\mathrm{a}}{ }^{\mathrm{b}}$ Std.Deviation & 6,633 \\
\hline Most Extreme Absolute & 117 \\
\hline Differences Positive & 108 \\
\hline Negative &,- 117 \\
\hline
\end{tabular}

\begin{tabular}{|l|l|}
\hline Test Statistic &, 117 \\
\hline Asymp. Sig. (2-tailed) &, $073^{\mathrm{c}}$ \\
\hline
\end{tabular}

- Test distribution is Normal

- Calculated from data

Dengan bantuan SPSS versi 22 hasil uji pada tabel 4.5 menunjuka bahwa nilai variabel, yaitu variabel perhatian orang tua nilai sig. $=0,073>0,05$. Sehinga dapat disimpulkan bahwa data di atas berdistribusi normal.

a. Hasil Uji Normalitas Minat

Tabel 4.6

Descriptive statistik

\begin{tabular}{|l|l|l|l|l|l|}
\hline & N & Mean & $\begin{array}{l}\text { Std. } \\
\text { Deviation }\end{array}$ & Min & Max \\
\hline Minat & 52 & 88,25 & 6,3898 & 73 & 100 \\
\hline
\end{tabular}

Tabel 4.7

One-Sample Kolmogorov-Smirnov Test

Test distribution is Normalalculated from data

\begin{tabular}{|c|c|c|}
\hline & & Minat \\
\hline $\mathrm{N}$ & & 52 \\
\hline Normal & Mean & 88,25 \\
\hline Parameters ${ }^{\mathrm{a} ’ \mathrm{~b}}$ & Std.Deviation & 6,389 \\
\hline Most Extreme & Absolute &, 096 \\
\hline Maxfferences & Positive &, 093 \\
\hline & Negative &,- 096 \\
\hline Opest Statistic & &, 096 \\
\hline Asymp. Sig. (2 & ed) & ,200 \\
\hline
\end{tabular}

Dengan bantuan SPSS Versi 22 hasil uji pada tabel 4.7 menunjukan bahwa nilai variabel, yaitu variabel Minat nilai sig. $=0.200>0.05$. sehingga dapat disimpulkan bahwa data di atas berdistribusi normal.

Hasil Uji Nomalitas Prestasi

Tabel 4.8 Descriptive Statistik

\begin{tabular}{|l|l|l|l|l|}
\hline $\mathrm{N}$ & Mean & Std. & Min & Max \\
\hline
\end{tabular}




\begin{tabular}{|l|l|l|l|l|l|}
\hline & & & Deviation & & \\
\hline Minat & 52 & 69,42 & 9,498 & 50 & 83 \\
\hline
\end{tabular}

Tabel 4.9

One-Sample Kolmogorov-Smirnov Test

\begin{tabular}{|c|c|c|}
\hline & \multicolumn{2}{|r|}{ Minat } \\
\hline $\mathrm{N}$ & \multicolumn{2}{|r|}{52} \\
\hline Normal & Mean & 69,42 \\
\hline Parameters & \multicolumn{2}{|c|}{ a'b 9,498} \\
\hline on & Std.Deviati & \\
\hline Most Extreme & Absolute & 109 \\
\hline Differences & Positive &, 109 \\
\hline & Negative &,- 101 \\
\hline Test Statistic & &, 109 \\
\hline Asymp. Sig. (2 & ed) &, $180^{\mathrm{c}}$ \\
\hline
\end{tabular}

- Test distribution is Normal

- Calculated from data

Dengan bantuan SPSS versi 22 hasil pada tabel 4.9 menunjukan bahwa nilai variabel, yaitu variabel Prestasi Belajar Siswa nilai sig. $=0.180>$ 0.05. sehingga dapat di simpulkan bahwa data diatas berdistribusi normal.

\section{Uji Lineritas Data}

Uji liniaritas dilakukan untuk mengetahui hubungan antara variabel dependen dengan variabel independen. Hasil uji linieritas menunjukanbahwa semua variabel dalam penelitian ini memiliki hubungan yang linier. Uji linieritas dalam penelitian ini menggunakan uji linearity dengan bantuan program spss v22. "jika Sig. Deviation From Liniaritylebih besar atau sam dengan taraf signifikansi yang dipakai $(0,05)$ berarti berkorelasi linier".

linieritas dengan bantuan program SPSS V22. “jika Sig. Deviation From Liniaritylebih besar atau sam dengan taraf signifikansi yang dipakai $(0,05)$ berarti

$$
\text { Tabel } 4.10
$$

Rangkuman hasil Pengujian Linieritas

\begin{tabular}{|l|l|l|l|l|}
\hline Variabel & $\begin{array}{l}\text { Sig. } \\
\text { Deviatio } \\
n \\
\text { from } \\
\text { Linierity }\end{array}$ & $\begin{array}{l}\text { Traf } \\
\text { Signifik } \\
\text { ansi }\end{array}$ & $\begin{array}{l}\text { Kesi } \\
\text { mpul } \\
\text { an }\end{array}$ \\
\hline 1 & $\begin{array}{l}\text { Perhatian } \\
\text { Orang } \\
\text { Tua dengan } \\
\text { Prestasi } \\
\text { Belajar } \\
\text { Siswa }\end{array}$ & 0,128 & 0,05 & $\begin{array}{l}\text { Linie } \\
\mathrm{r}\end{array}$ \\
\hline 2 & $\begin{array}{l}\text { Minat dengan } 0,149 \\
\text { Prestasi } \\
\text { Belajar Siswa }\end{array}$ & 0,05 & $\begin{array}{l}\text { Linie } \\
\mathrm{r}\end{array}$ \\
\hline
\end{tabular}

Sumber : Data Primer yang diolah

Uij linieritas antara variabel bebas (perhatian orang tua dan minat) dengan variabel terikatnya (prestasi belajar siswa) dilihat dari deviation from linearity, menurut hasil perhitungan didapatkan nilai deviation from linearity sebesar 0,128 pada taraf signifikansi 5\% antara variabel Perhatian orang tua dengan prestasi belajar siswa, sebesar 0,149 antara minat dengsn prestasi belajar siswa.

Menurut kriterianya adalah jika harga deviation from linearity lebih besar dari taraf signifikansi yang diambil $(5 \%)$ berarti linier. Dalam penelitian ini terbukyi bahwa deviation from linearity antara variabel bebas dengan variabel terikatnya adalah lebih besar terhadap taraf signifikansinya $(0,05)$, maka dapat disimpulkan bahwa pengaruh antara perhatian orang tua dengan prestasi belajar siswa bersifat linier.

\section{Pengujian Hipotesis}

1.Uji Hipotesis 1 (Perhatian Orang Tua * Prestasi)

Hasil perhitungan pada tabel Mode Summary, menunjukan bahwa nilai $\mathrm{R}$ $=0,417$ dan koefisien determinasi (Rsquare) sebesar $\quad 0,174 \quad$ (adalah pengkuadratan dari koefisien regresi, atau 


\section{$0,417 \times 0,417=0,174)$.}

Hal ini menunjukan pengertian bahwa prestasi belajar siswa (Y) dipengaruhi sebesar $17,40 \%$ oleh oleh perhatian orang tua $(\mathrm{X})$, sedangkan sisanya $(100 \%-17,40 \%=82,60 \%)$ dipengaruhi oleh sebab-sebab lain. Maka Ho di tolak dan $\mathrm{H} 1$ diterima,

yang berarti ada pengaruh yang nyata (signifikansi) variabel Perhatian Orang Tua $\left(\mathrm{X}_{1}\right)$ terhadap variabel Prestasi Belajar (Y).

\section{Uji Hipotesi 2 (Minat * Prestasi)}

Hasil perhitungan pada tabel Model Summary, menunjukan bahwa nilai $\mathrm{R}=$ 0,415 dan koefisien Determinasi (Rsquare) sebesar 0,172 (adalah pengkuadratan dari koefisien regresi, atau $0,415 \times 0,415=$ $0,172)$. Hal ini menunjukan pengertian bahwa prestasi belajar siswa (Y) dipergunakan sebesar $17,20 \%$ oleh minat belajar siswa $\left(\mathrm{X}_{2}\right)$, sedangkan sisanya $(100 \%-17,20 \%=82,80 \%$ dipengaruhi oleh sebab- sebab lain. Maka Ho ditolak Dan H1 diterima, yang berarti ada pengaruh yang nyata (signifikansi) variabel Minat ( $\mathrm{X}_{2}$ ) terhadap variabel Prestasi Belajar $(\mathrm{Y})$

3. Uji Hipotesis \# ( Prestasi dan Minat* Prestasi Belajar)

Hasil perhitungan pada tabel Summary,

menunjukan bahwa nilai $\mathrm{R}=0,417$ dan koefisien determinasi (Rsquare) sebesar 0,174 (adalah pengkuadratan dari koefisien regresi, atau $0,417 \times 0,417$ $=0,174$ ).

Hal ini menunjukan pengertian bahwa prestasi belajar dipengaruhi sebesar 17 , $40 \%$ oleh perhatian orang tua $\left(\mathrm{X}_{1}\right)$ dan minat $\left(\mathrm{X}_{2}\right)$ secara bersama-sama, sedangkan sisanya $(100 \%-17,40 \%=$ $82,60 \%$ ) dipengaruhi oleh sebab-sebab lain. Maka Ho ditolak dan H1 diterima, yang berarti ada pengaruh yang nyata (signifikansi) variabel Perhatian Orang Tua $\left(\mathrm{X}_{1}\right)$ dan Minat $\left(\mathrm{X}_{2}\right)$ terhadap variabel Prestasi Belajar (Y).

B. Hasil Pengujian Hipotesis

Berdasarka pengujian hipotesis yang dilakukan, maka dapat dikemukakan hasil-hasil pengujian hipotesis sebagai berikut :

1. Dari hasil analisis regresi sederhana menunjukan bahwa terdapat pengaruh yang signifikan antara perhatian orang tua terhadapprestasi belajar siswa SMK Negeri 1 Tomohon, Hipotesi H1 diterima.

2. Dari hasil analisis regresi sederhana menunjukan bahwa terdapat pengaruh yang signifikan antara minat terhadap prestasi belajar siswa SMK Negeri 1 Tomohon, Hipotesis H1 diterima.

3. Dari hasil analisis regresi ganda menunjukan bahwa terdapat pengaruh yang signifikan anta perhatian orang tua dan minat terhadap prestasi belajar siswa SMK Negeri 1 Tomohon.

\section{Pembahasan}

Pengaruh Perhatian Orang Tua Terhadap Prestasi Belajar Siswa SMK Negeri 1 Tomohon

Berdasarkan hasil pengujian hipotesis, menunjukan bahwa terdapat pengaruh yang signifikan antara perhatian orang tua dengan prestasi belajar siswa SMK Negeri 1 Tomohon di Tomohon Barat. Hal ini berarti perhatian orang tua memberikan konstribusi yang sedikit terhadap prestasi belajar siswa SMK Negeri 1 Tomohon yang dilihat pada Hasil perhitungan pada tabel Mode Summary, menunjukan bahwa nilai $\mathrm{R}=0,417$ dan koefisien determinasi (Rsquare) sebesar 0,174 (adalah pengkuadratan dari koefisien regresi, atau $0,417 \times 0,417=0,174)$. Hal ini menunjukan pengertian bahwa prestasi belajar siswa (Y) dipengaruhi sebesar $17,40 \%$ oleh oleh perhatian orang tua (X), sedangkan sisanya $(100 \%-17,40 \%$ $=82,60 \%$ ) dipengaruhi oleh sebabsebab lain. Maka Ho di tolak dan H1 diterima, yang berarti ada pengaruh 
yang nyata (signifikansi) variabel Perhatian Orang Tua $\left(\mathrm{X}_{1}\right)$ terhadap variabel Prestasi Belajar (Y).

Pengaruh Minat Terhadap Prestasi Belajar Siswa SMK Negeri 1 Tomohon

Berdasarkan hasil pengujian hipotesis, menunjukan bahwa terdapat pengaruh yang signifikan antara minat dengan prestasi belajar siswa SMK Negeri 1 Tomohon di Tomohon Barat. Hal ini berarti minat belajar memberikan konstribusi yang sedikit terhadap prestasi belajar siswa SMK Negeri 1 Tomohon yang dilihat pada hasil perhitungan Hasil perhitungan pada tabel Model Summary, menunjukan bahwa nilai $\mathrm{R}=0,415$ dan koefisien Determinasi (Rsquare) sebesar 0,172 (adalah pengkuadratan dari koefisien regresi, atau $0,415 \times 0,415$ $=0,172$ ).

Hal ini menunjukan pengertian bahwa prestasi belajar siswa (Y) dipergunakan sebesar 17,20\% oleh minat belajar siswa $\left(\mathrm{X}_{2}\right)$, sedangkan sisanya $(100 \%-17,20 \%=82,80 \%$ dipengaruhi oleh sebab-sebab lain. Maka Ho ditolak Dan H1 diterima, yang berarti ada pengaruh yang nyata (signifikansi) variabel Minat $\left(\mathrm{X}_{2}\right)$ terhadap variabel Prestasi Belajar (Y)

Pengaruh Perhatian Orang Tua dan Minat Terhadap Prestasi Belajar Siswa SMK Negei 1 Tomohon

Berdasarkan hasil pengujian hipotesis, menunjukan bahwa terdapat pengaruh yang signifikan antara perhatian orang tua dan minat secara bersama-sama dengan prestasi belajar siswa SMK Negeri 1 Tomohon di Tomohon Barat. Hal ini, berarti perhatian orang tua dan minat memberikan konstribusi yang sedikit terhadap prestasi belajar siswa SMK Negeri 1 Tomohon yang di lihat pada hasil Hasil perhitungan pada tabel Summary, menunjukan bahwa nilai $\mathrm{R}=$
0,417 dan koefisien determinasi (Rsquare) sebesar 0,174 (adalah pengkuadratan dari koefisien regresi, atau0,417x 0,417=0,174).

Hal ini menunjukan pengertian bahwa prestasi belajar dipengaruhi sebesar $17,40 \%$ oleh perhatian orang tua $\left(\mathrm{X}_{1}\right)$ dan minat $\left(\mathrm{X}_{2}\right)$ secara bersamasama, sedangkan sisanya $(100 \%$ $17,40 \%=82,60 \%)$ dipengaruhi oleh sebab-sebab lain. Maka Ho ditolak dan H1 diterima, yang berarti ada pengaruh yang nyata (signifikansi) variabel Perhatian Orang Tua $\left(\mathrm{X}_{1}\right)$ dan Minat $\left(\mathrm{X}_{2}\right)$ terhadap variabel Prestasi Belajar (Y).

\section{KESIMPULAN DAN SARAN}

\section{Kesimpulan}

Hal ini menunjukan pengertian bahwa prestasi belajar dipengaruhi sebesar $17,40 \%$ oleh perhatian orang tua $\left(\mathrm{X}_{1}\right)$ dan minat $\left(\mathrm{X}_{2}\right)$ secara bersamasama, sedangkan sisanya $(100 \%$ $17,40 \%=82,60 \%)$ dipengaruhi oleh sebab-sebab lain. Maka Ho ditolak dan H1 diterima, yang berarti ada pengaruh yang nyata (signifikansi) variabel Perhatian Orang Tua $\left(\mathrm{X}_{1}\right)$ dan Minat $\left(\mathrm{X}_{2}\right)$ terhadap variabel Prestasi Belajar (Y).

\section{Saran}

Berdasarkan hasil kesimpulan di atas maka dapat disarankan sebagai berikut

1. Berkaitan dengan tanggung jawab orang tua, maka orang tua harus lebih banyak memperhatikan, memberi semangat, membantu dan mendorong anaknya agar berprestasi terlebih kusus dalam dunia pendidikan.

2. Perlu adanya peningkata minat belajar dari siswa agar siswa terdorong untuk mencapai citacitanya dan meningkatkan kemampuan belajarnya agar mendapat prestasi belajar yang lebih 
baik.

3. Bagi peneliti selanjudnya disarankan untuk menambah variabel lain yang berpengaruh terhadap pencapaian prestasi belajar siswa, diantaranya mengenai kompetensi guru, metode mengajar, disiplin, bakat, lingkungan, dan sebagainya.

\section{DAFTAR PUSTAKA}

Arikunto, Suharsimi. 2010.Prosedur Penelitian Suatu Pendekatan Praktik. Jakarta : Rineka

Cipta.

Arikunto, Suharsimi. 2006.prosedur Penelitian Suatu Pendekatan Praktik. Jakarta : Rineka Cipta. 2006. Metode Penelitian Kuantitatif. Bandung : Alfabeta.

Departemen Pendidikan Nasional. 2001. Kamus Besar Bahasa Indonesia.Jakarta. Balai Pustaka

Dimyati, Mudjiono. 2006. Belajar dan Pembelajaran . Jakarta:Rineka

Cipta.

Sudarsono, max, dkk. 2000. Belajar dan Pembelajaran. IKIP Semarang Press.

Sugiyono, Metode Penelitian Kuantitatif, Kualitatif dan $R \quad \& \quad D$. Robert Gague, $\quad 1988 . \quad$ Prinsip-prinsip Belajar Untuk Pengajaran di Sekolah. Surabaya : Usaha Nasional Slaneto, 1988. Belajar dan FaktorFaktor yang

Mempengaruhinya.Jakarta : PT. Bina Aksara

Sutrisno Hadi, 1987. Metodologi Reseach II. Yogyakarta : Yayasan Penerbit Fakultas Psikologi UGM, 1990. Metodologi Reseach III, Yogyakarta : Yayasan Penerbit Fakultas Psikologi UGM

Sudirman,2001. Interaksi Belajar Mengajar. Jakarta: Raja Grafindo Persada

Slameto. 2003. Belajar dan Faktor-
Faktor yang

Mempengaruhinya.Jakarta: Rineke Cipta Sugiono. 2001. Statistik untuk Penelitian. Bandung: Afabeta.

Surtano NS. 2001. Perpustakaan dan Masyarakat. Jakarta : Sagung Seto

$\mathrm{Tu}$ ' u, Tulus. 2002. Peran disiplin pada perilaku dan prestasi

siswa.Jakarta: Grasindo.

Thomas Gordon, 1983. Menjadi Orang Tua Efektif. Jakarta : PT.Gramedia

Winkel W. S. 1983 Bimbingan dan Konseling di Sekolah Menengah.Jakarta: PT. Gramedia.

Zainal Mustofa, 1991, Prosedur Penelitian, Jakarta : CV. Persada. 